\title{
El concepto de relación. Consideraciones epistemológicas sobre el valor cognoscitivo de la ficción.
}

\section{The concept of relationship. Epistemological considerations about the cognitive value of fiction.}

\author{
Gutiérrez Delgado, R. ${ }^{1}$ \\ Recibido: 10-05-2018 - Aceptado: 26-06-2018 \\ DOI: https://doi.org/10.26441/RC17.2-2018-A13
}

RESUMEN: Este artículo desarrolla la categoría de la relación, según la describe Aristóteles en su Órganon, con el fin de establecer un fundamento cognoscitivo de la ficción audiovisual, en el contexto del debate acerca del referente, puesto en crisis por algunas teorías como el estructuralismo, la semiótica, los Cultural Studies o la narratología. Por otra parte, la aplicación de la relación al objeto audiovisual implica poner en diálogo cuatro obras esenciales de Aristóteles (la Poética, la Ética nicomaquea, el Órganon y la Retórica), privilegiando la naturaleza dramática de la ficción audiovisual sobre la narrativa y subrayando la necesidad y la verosimilitud como los rasgos de la dimensión lógica de las ficciones.

En el estudio se revisa el concepto aristotélico de mímesis praxeos, entendido como representación frente a la interpretación limitada de la mímesis platónica, desligada de la "praxis" y descalificada como antifilosófica (por triple degradación de las ideas).

Palabras clave: relación; mímesis praxeos; representación; dimensión lógica; razonamiento poético.

\begin{abstract}
This article develops the notion of relationship described by Aristotle in his Órganon, in order to establish a cognitive foundation for audiovisual fiction. The discussion is framed in the context of a certain contention about the concept of reference, brought into question by theoretical approaches such as structuralism, semiotics, the field of cultural studies, and narratology. Concurrently, the application of the notion of relationship to the audiovisual object implies the creation of a dialogue between four of the essential works of Aristotle (Poetics, Nichomachean Ethics, Organ and Rhetoric), emphasizing the dramatic nature of audiovisual fiction over its narrative quality, while underscoring the concepts of need and verisimilitude as the main traits of its logical dimension.

Through this study, the Aristotelian concept of mimesis praxeos is reviewed within the framework of representation, as opposed to the more limited interpretation of the Platonic mimesis, which is separated from praxis and consequently rejected as anti-philosophical (by way of the triple degradation of ideas.)
\end{abstract}

Keywords: relationship; mimesis praxeos; representation; logical dimension; poetic syllogism.

1 Ruth Gutiérrez Delgado es Doctora en Comunicación Pública por la Universidad de Navarra y Profesora de Guión de Ficción I (series) y Epistemología de la Comunicación de la Facultad de Comunicación de la misma universidad. rgutierrez@unav.es, http://orcid.org/0000-0002-7258-3466 


\section{Introducción}

Los estudios sobre Poética y Teoría de la Representación en la ficción audiovisual se han abordado desde distintos enfoques y planteamientos. El más sugerente es sin duda el rescate de la Poética de Aristóteles (Ricoeur, 1975, 1983, 1987), actualizado y aplicado al lenguaje audiovisual (García-Noblejas, 1982, 1996) y llevado como novedad al ámbito de la práctica industrial, a través de la teoría del guion, "the screenwriting theory", con una clara recuperación del concepto de unidad de acción, "the screen idea", del tema y del sentido (Macdonald, 2003, 2013; Brenes, 2011, 2016); esa misma línea de investigación -y poniendo a dialogar otras obras de Aristóteles como el Órganon- también ha dado como fruto un estudio sobre el origen y las consecuencias poéticas de la "falacia dramática" en la ficción televisiva y cinematográfica; a causa de las intromisiones de la industria y de los factores contextuales en la escritura del guión, se producen discordancias y alteraciones de su sustrato lógico, rompiendo así la unidad diegética de la historia (Gutiérrez, 2008; Torrado, 2017).

Por otra parte, entre otras aproximaciones, destacan la narratología (Genette, 1969), el estructuralismo y la semiótica (Culler, 1975; Eco, 1976; Greimas, 1987; Barthes, 1977), que han proclamado la autonomía del texto poético sin despreciar por completo el texto de la Poética; en cambio, en las antípodas del neoaristotelismo, se encuentran los Cultural Studies (Hall, 1964; Schatz, 2014) cuyas revisiones suponen más una crítica de la cultura y de la recepción que una teoría propiamente dicha. En esa línea, los Cultural Studies, -nombre con el que se denomina a una amplísima variedad de teorías y métodos críticos de origen marxistaabogan por revisar, desde posicionamientos marco, las representaciones, creencias, imágenes, categorías expresadas a la luz de los intereses de clase que los han podido generar (Frow, 1992); así mismo, establecen la necesidad de revaluar y decodificar el significado de los textos, evitando la universalización de los juicios, y, por lo tanto, eliminando así la posibilidad de toda validez ética. Así han generado metodologías de análisis del discurso como la de la "teoría de los contextos de Grossberg” (Kovala, 2014) y la de la "articulación" (Slack, 2006) con la finalidad de buscar y desenmascarar significados ocultos e intereses de clase presentes en los textos, haciendo un esfuerzo de carácter epistemológico abocado a la aporía.

Estos acercamientos (desde sus enfoques y presupuestos) han desarrollado aspectos tan específicos y diversos como, por ejemplo, las instancias del texto, la creación de los personajes, el estudio de los elementos del texto poético como signos lingüísticos y la unidad de significado, la autoría, la intención del autor, el sentido del texto, la estructuración mítica de la trama, el viaje del héroe o la fundamentación teórica en el área de escritura de guiones. La didáctica a este respecto distingue entre la teoría, como un modo de hacer ciencia del arte de la ficción y sus consecuencias conceptuales y las herramientas 
que ayudan a la creación de buenas historias.

No obstante, el gran escollo con el que tropiezan algunos enfoques estructuralistas (García-Noblejas, 1982) y los Estudios Culturales sigue siendo el problema del referente real: es decir, si la ficción remite o no a lo real y de qué manera lo hace. Dicho de otro modo, si la ficción puede decir verdades acerca del hombre y su situación o por el contrario, es un objeto autónomo, que es referente para sí mismo, de naturaleza estética, sin fin final. El tema no es fácil: pues aunque el sentido común dice que, en general, el público busca entender algo en las historias a la par que las disfruta, en el plano de la academia es donde se concentran las dificultades y las disputas, en parte, por el valor aparencial que se le otorga a las imágenes. A este respecto, y teniendo en cuenta los trabajos de "retención" y de "reelaboración” con los que se producen las obras audiovisuales, resulta sugerente, razonable y problemática (como una explicación básica al reproche epistemológico planteado) la distinción que hace Ferraris entre la imaginación y la fantasía: “(...) imaginación es la retención de lo ausente, la fantasía se inclina hacia lo irreal más que la imaginación. Como quiera que la reelaboración es más tendente a la falibilidad que la retención, la fantasía se inclina hacia lo irreal más que la imaginación" (1999: 11). Este tema requeriría una investigación mucho más amplia que la que se ofrece aquí. Pues como señala Ferraris a veces la imaginación se define como fantasía, en el sentido platónico de "re- presentación verídica" o como "apariencia ilusoria” (1999: 12). En ese sentido, el estudio sobre la relación es un punto de partida para aclarar desde la lógica un proceso de transformación e inteligencia de la realidad que puede concurrir en la verdad o falsedad de algo; parece interesante situar el tema en ese estado complejo, explicar el origen del problema y aportar una solución conceptual.

En suma, lo que se pone en duda en última instancia es si cabe o no afirmar que la ficción puede ser vehículo de conocimiento y que, en consecuencia, se pueden sacar juicios de verdad o falsedad poéticas, y también consecuencias morales y responsabilidades sociales de los cineastas y gentes de la industria.

En primer lugar, con el objetivo de abordar el problema descrito, aclararemos la premisa a partir de la cual derivamos el interés por la dimensión lógica de la ficción. En concreto, lo que planteamos aquí es que cuando se crea una historia, se genera una relación natural entre el objeto artificial (la obra audiovisual) y lo real. Por "lo real", y para que se entienda correctamente, vamos a tomar prestada la idea que tiene Aristóteles sobre qué se representa en las historias: la praxis humana, una "sola y entera" acción práctica o lo que los hombres hacen, cómo actúan (Poética, 1448a, 1; 1448a, 28-29; 1449b, 24-26; 1451a, 30-33). Dicho esto, a partir de ahora se usará "praxis humana" para referirnos a hombres que actúan y acción humana.

Pues bien: lo que proponemos es que (1) existe una relación entre la praxis 
humana y la ficción y (2) esa relación da forma al relato, lo organiza, intentando espejar cómo es esencialmente lo que hacemos los hombres, aquí, ahora y siempre, esto es, de manera universal. El argumento de la trama puede reflejar el modo de actuar humano de manera universal. Y esto se produce gracias a esa relación.

En segundo lugar, para abordar el tema de la lógica correctamente, hemos de recurrir conjuntamente a la Poética de Aristóteles y al Órganon, pues, en última instancia, se trata de aplicar un concepto de la lógica a la poética. En esto nos será de gran ayuda apoyarnos en el pensamiento de algunos de sus seguidores más concienzudos y atinados, sin un orden cronológico sino discursivo: en Paul Ricoeur, para hacer una lectura profunda acerca de la mímesis praxeos en Aristóteles y en los comentaristas árabes medievales: Averroes, Alfarabi y Avicena, para tratar el carácter proposicional de las metáforas. Irnos tan lejos para llegar tan cerca es siempre un viaje que merece la pena. Pues el estudio específico de los aspectos lógicos y cognitivos de las historias de ficción audiovisual plantea todavía un terreno fértil pero difícil para el crecimiento de la investigación académica. Por lo tanto, además de seguir avanzando en esta línea, parte del objetivo de este artículo es lograr aclarar algunos términos esenciales.

En suma, en primer lugar, se analizan las dificultades y consecuencias de asumir el arte poética como mera mímesis y como mímesis praxeos; en segundo lugar, se estudia la dimensión racional de la mímesis praxeos para, en tercer lugar, explicar cómo la relación actúa de vínculo entre la ficción y la acción práctica, explicando así la existencia metafórica y coexistente, por tanto, de la ficción, frente a una supuesta autonomía autojustificada en sí; en cuarto lugar, se hace necesario exponer las razones por las que dicha relación no sólo afecta al modo en que se organiza la ficción (pragmaton systasis) y al qué (mímesis praxeos), sino a que es condición para abrir el objeto poético al conocimiento, al juicio de verdad o falsedad. De este modo, y en quinto lugar, se consolida la necesidad de estudiar las ficciones como "silogismos poéticos", desde el punto de vista lógico y retórico, abordando los principios que los definen.

Como decíamos, vamos al origen de la disputa epistemológica: la postura platónica y la postura aristotélica.

\section{La vuelta a Platón y la estela aristo- télica}

Gran parte de la razón por la que, en los últimos tiempos, se ha puesto en duda la existencia de un referente real para las ficciones tiene sus orígenes en la brecha epistemológica abierta entre la visión de la mímesis en Platón y la visión de la mímesis praxeos de Aristóteles (Mete, 2018: 216). Pese al tiempo transcurrido, aún sigue estando vigente (Llano, 2014: 21-28). Estos dos modos de entender el mito poético y la recepción de la obra han generado una abundante literatura al respecto (Halliwell, 1998; Ehrat, 2005). Para detallar algunas diferencias claras que confluyen en el esfuerzo por explicar la relación como 
una categoría de la lógica de la ficción, se han tenido en cuenta especialmente las aportaciones de Verdenius (1949) y Golden (1992), en el caso de la interpretación de la mímesis platónica, y de Ricoeur (1987), para fundamentar la dimensión lógica del mythos, entendido como operación o proceso de construcción de la trama (pragmaton systasis) y como actividad mimética (mímesis praxeos), en tanto que representación de una sola acción. En este último caso, la referencia a Ricoeur resulta útil sólo en cierta medida, pues, -aunque no es objetivo principal de este trabajo plantear algunas contradicciones encontradas en Tiempo y Narración que, en cualquier caso, animan a pensar en la viveza y amplitud de su pensamiento-, Ricoeur sostiene que "el pleno desarrollo del concepto de mímesis exige que se dé menos importancia a la relación referencial al dominio real de la acción, y que este dominio reciba otras consideraciones distintas de las éticas -por lo demás, considerables- que le asigna Aristóteles (...)" (1987a: 84). Es decir, que Ricoeur reste importancia al referente de la praxis, al obrar, y, a la vez, afirme la importancia de entender el mythos como representación de la acción no parece muy acertado cuando lo que predomina en la visión poética de la mímesis aristotélica es precisamente la praxeos ética vinculada a la mímesis creadora:

Sin embargo, la ecuación entre mímesis y mythos no colma el sentido de la expresión mímesis praxeos. Es cierto que se puede construir (...) el genitivo de objeto como el correlato neomático de la imitación (o de la repre- sentación) y emparejar este correlato con la expresión completa «disposición de los hechos", que para Aristóteles constituye el «qué» -el objeto- de la mímesis. Pero la pertenencia del término praxis a la vez al dominio de lo real, propio de la ética, y al imaginario, propio de la poética, sugiere que la mímesis no tiene sólo una función de corte, sino de unión, que establece precisamente el estatuto de transposición «metafórica» del campo práctico por el mythos (Ricoeur, 1987: 107).

Ricoeur quiere definir el acto de representar como una acción en sí ("la acción es lo «construído» de la construcción en que consiste la actividad mimética") (1987: 89), con carácter operante (86); "que actúa como el espíritu humano" (García-Noblejas, 1988: 46), para lograr "«ser-como", en el plano ontológico más radical”, (1987: 35; 85-86) ; es decir: tramar una historia es ya imitar la acción, crear el "como-si" (1987: 106). Este no es un aspecto menor a considerar. Pues la relación de semejanza es el fundamento lógico y la base de la propensión veritativa del mythos. El mito (mythos), entendido como esa operación, capta "lo inteligible de lo accidental" (Ricoeur, 1987: 100) de una acción práctica vivida (y recordada o revivida por el autor), observada y comprendida y desarrolla las posibilidades esenciales hasta mostrar sus últimas consecuencias para las personas. Cosa que no ocurre en la realidad de manera plena y reconocida. Es decir, la praxis impregna a la mimesis hasta el punto de constituirla, de ser su fundamento 
ontológico (1987: 89). Por ello, antes de avanzar en nuestra exposición, es necesario definir el plano en el que la relación, como categoría lógica imbricada en la operación poética, actúa como instrumento de racionalidad en la ficción a través de la necesidad que obtiene de comportarse como lo hace un ser humano cuando actúa (Poética, 1452a, 10, 19-20). Gracias a esa relación, la ficción se deja conocer y somos capaces de conocer.

Según Ricoeur, respecto del "vínculo interno de la trama que es más lógico que cronológico", Aristóteles "no se pronuncia porque se trata de una inteligibilidad apropiada al campo de la praxis y no de la theoria, próxima a la phronesis, que es la inteligencia de la acción" (1987a: 97). A mi modo de ver, que no se desarrollen los detalles de la racionalidad poética en la Poética y sólo se mencionen sus fundamentos sólo indica que no es el lugar. Podría suponerse simplemente que, como en el caso de las características de las acciones y de los hábitos, los conocimientos sobre lógica ya los había definido en el Órganon, al hablar de los silogismos, como razonamientos, (Analíticos primeros, 24b, 18, 22), y en la Retórica, al explicar los entimemas (1356b, 4-5) como "razonamientos probables" usados en la oratoria (Tópicos, I, 1, 100a 25 y 12, 105a 13). Ese es el nivel de la argumentación silogística. Parece que la ficción comparte con la dialéctica un sustrato argumental de carácter demostrativo, a través del cual también podemos entrever en las historias que "dadas ciertas proposiciones, otra de ellas resulte a su lado por existir ellas o absolutamente o por la mayor parte, [se llama allí silogismo, aquí entimema]" (Retórica, I, 2, 1356b, 15-20). Esto es, de las ficciones se pueden deducir propuestas no sólo para pensar, sino para actuar, y este trabajo deductivo se suele hacer de manera inconsciente.

Para comprender el valor racional del mythos aristotélico y su importancia en las ficciones audiovisuales hay que descender a dicha base de la lógica con cierto rigor, sabiendo que su principio configurador es una relación de semejanza, por la que se atribuirán cualidades y connotaciones diferenciales a un acción particular, que a través de la ficción es elevada al rango de universal en el plano del significado, como el objeto al que remite, por un lado y del sentido, como el fin, el para qué, el aspecto teleológico, con orientación extraliteraria. por otro, según García-Noblejas (1982: 47, 55, 58, 110). Esa relación con la acción práctica se materializa en una acción concreta, simbólica y única capaz de catalizar narrativamente tanto lo universal como lo particular implicado en la acción real. Por ejemplo, desde qué significa perder la identidad por conseguir un buen trabajo y una buena reputación en una revista de moda (El diablo viste de Prada, 2006) hasta ver cómo podemos revivir la infancia al degustar un bocado de un plato exquisito (Ratatouille, 2007).

\section{La relación: la categoría de la coe- xistencia}

Según dice Aristóteles en el Libro de las Categorías (Organon, Parte I, capítulo 4), "llamamos relativa a una cosa 
cuando se dice que ella existe del modo que existe, porque existe en dependencia de otra cosa, o bien, si no, porque su existencia está referida o relacionada con algo de alguna otra manera”. Esta categoría explica cómo las semejanzas entre las cosas pueden posibilitar la comparación. De este modo, se entiende que la relación pone de manifiesto las semejanzas entre dos objetos y destaca así con qué se relaciona el objeto (Org. I, 4). Llevado al ámbito audiovisual, está claro que de manera palpable las ficciones audiovisuales, por estimularnos con imágenes y sonidos, recurren constantemente a la relación con la realidad, ya sea para emularla o para transformarla. Pero insistamos un poco más en los asuntos relativos que tienen cabida real en las ficciones. Entre los "relativos", enumera Aristóteles también al "hábito", a la "disposición", a la "percepción", a la "posición o actitud" y al "conocimiento":

Todos ellos se explican por medio de una referencia a algo que ellos poseen y no de otra cualquier manera. Un hábito es un hábito de algo; el conocimiento es conocimiento de algo; la posición es posición de algo. Hablamos, pues, de términos relativos cuando la existencia de una cosa es de tal clase que se explica por medio de un genitivo consecuente, o bien por alguna frase o expresión destinada a poner en evidencia la relación (...) (Org. I, 7).

La pregunta es si cabría entender la mímesis o la representación como términos relativos, pues su existencia se explica claramente por la existencia de otra cosa. De ahí que hablemos de coexistencia: el mythos necesita lo real para ser comprendido y lo real recurre al mythos para comprender y hallar sentido. Aquí cabría pensar incluso en cómo las adaptaciones y los remakes son claramente ejemplos de obras cuya existencia se da por relación con otras obras².

Por descender a los detalles teóricos y anticipar la reflexión sobre la racionalidad de las ficciones, para el caso general de la mímesis, ya en la Retórica, Aristóteles afirma que el placer que se logra a través de la imitación "no es el goce sobre ello mismo, sino que hay un razonamiento de que esto es aquello, de manera que resulta que se aprende algo" (I, 11, 9-10). El factor de aprendizaje en el proceso mimético (Aristóteles, Poética, 1448b, 4-10) es un rasgo esencial de la visión aristotélica de la mímesis (Worth en Mete, 2018: 219; Scaramuzzo, 2016: 251; Halliwell, 2002: 192). Reconocer produce deleite; pero Aristóteles también advierte de que lo reconocido ya existe (Poética, 1448b, 15-19): "Por eso, en efecto, disfrutan viendo imágenes, pues sucede que, al contemplarlas, aprenden y deducen qué es cada cosa, por ejemplo, que éste es aquél".

2 En el terreno de los Estudios de Adaptación continúa el debate sobre el "referente original" de las obras. Cfr. Frago, M. (2005). "Reflexiones sobre la adaptación cinematográfica desde una perspectiva iconológica". Communication and Society, Vol. XVIII, 2: 49-82. 


\subsection{La naturaleza dependiente de la mímesis}

Otro aspecto que merece la pena señalar de la Poética de Aristóteles es que, al menos, tres veces, define el mythos como mimesis praxeos y como no mímesis a secas (de un proceso de copia) sino como "representación de una acción" (Ricoeur, 1987: 87-88). Con esto se señalan los dos elementos de una comparación que tiene carácter sintético, intensivo y no extensivo; donde ha habido una operación, un movimiento, (o producción, según Ricoeur) a través del cual somos capaces de ver una única acción preferentemente de hombres que actúan.

Más allá de la importancia que tiene haber indicado la segunda parte de la relación, de momento (pues dejaremos la observación sobre la representación para más adelante), interesa concentrar la atención en la mímesis como una operación o actividad cuyo ser es dependiente de la entidad de otro. Acerca del carácter de esa operación de relación, Ricoeur apunta a una doble función del acto poético: "el de la construcción de la trama (mythos) y el de la actividad mimética (mimesis)" (1987: 84). Tanto tramar como representar la acción son consideradas como operaciones y no acciones estáticas o estructuras (85) en las que se disponen hechos. Lo interesante de esta operación mimética es que la finalidad está fuera, no se mira a sí misma. Tanto el origen de la mímesis praxeos como su finalidad es la acción real posible. Por ello, Ricoeur define la Poética como "el arte de componer tramas" (86). Y es que Aristóteles define "la ac- ción" como «la parte principal», el «fin buscado», el «principio» de la mímesis praxeos. Si la acción está en el origen de la mímesis y en la finalidad de la historia, cabe preguntarse cómo aparece la relación de semejanza y en qué grado se alcanza un conocimiento relativo y completo a la vez sobre ella. Es decir, si el poeta/escritor/guionista inician su trabajo poético pensando en un acción concreta (inspirada, de la memoria, de la experiencia personal o de otros, de la imaginación...), transcurrida la elaboración de la ficción, llegan al conocimiento universal y al sentido de la acción. Esto sucede en la operación de relacionar. En última instancia lo que está en juego es saber si la consistencia argumental de la ficción dramática depende de la relación con el referente real, del que extrae su esencia. Pues la perfección del proceso mimético depende de esa relación, no sólo de seguir escrupulosamente unas pautas técnicas.

\subsection{Mímesis o mímesis praxeos}

Las visiones de Platón y de Aristóteles sobre la poética son divergentes. Platón es pesimista respecto al arte poética y a los logros poéticos de los artistas y, en cambio, Aristóteles sostiene la operatividad del arte poética, distinguiendo la naturaleza de la Poética, por un lado, del hecho de que existan malos poetas, que son aquellos que crean historias episódicas y las alargan atentando contra su necesidad y verosimilitud (Poética, 1451b, 33-40). En lo que se refiere al principio del arte, Platón considera que la mimesis es su origen (Verdenius, 1949: 1). Pero acusado de racionalismo por su 
idea "científica" del arte, más sublime cuanto más cercano a la reproducción exacta de las Ideas, concluirá que las artes miméticas sólo producen apariencias; en ese sentido, la imposibilidad de hacerse con la Idea pura es para el poeta una condena, y para el arte en sí la exclusión del territorio de la Verdad. En lo que respecta al objeto imitado por los poetas -pues lo que no niega Platón es que exista un referente manifestado como en un espejo, esto es, simulado-, según Verdenius, se trata de una evocación, de aspectos inciertos sobre la conducta humana en lo que es posible vislumbrar (1949: 13): "Imitation implies transformation, and transformation implies confusion, if it is determined by a sphere of reality (in this case, the poetical mind) inferior to its object". En este punto, se ve que Platón también se refiere a la mímesis como representación y no como copia. El problema estriba en que en esa representación de los caracteres, de sus acciones, de sus emociones, de los objetos y demás relativos a la mímesis hay, según Platón, una pérdida de conocimiento de la realidad. Se trata de la triple degradación de las Ideas platónica. Para Platón, su idea de la mímesis es conceptual, según los niveles de realidad que establece con respecto a la idea pura o Forma. La mímesis es el nivel más alejado de la realidad, pues consiste en la imagen del modelo material, que sería el segundo nivel de realidad (Golden, 1992: 42). Por simplificar el modelo de triple degradación: el primer nivel de la realidad estaría constituido por las Formas; el segundo nivel por las imágenes del modelo material que los poetas se forman en su mente acerca de las Formas; y el tercer nivel lo completarían las obras ejecutadas por los poetas. En cada paso descendente (desde la Idea hasta la obra poética), dice Platón que se degrada la Forma: se pierde verdad. Es decir, los poetas hacen que la Realidad, las Formas, las Ideas puras se malogren porque son incapaces de hacerse con ellas en un sentido filosófico. Copian las "apariencias", pues no saben lo que las cosas son. Ante esta evidencia filosófica, Platón pone límites al arte, por pura responsabilidad moral: si los poetas van a divulgar y comunicar apariencias, más vale que lo hagan sobre personajes ejemplares y sobre cuestiones morales. Lo contrario es un mero y burdo engaño del pueblo.

Aún y todo, como establece Ricoeur, en su afán de conectar la postura aristotélica a la platónica en materia mimética:

Conservemos de Platón el sentido metafísico dado a la mímesis, en conexión con el concepto de participación, según el cual las cosas imitan a las ideas, y las obras de arte a las cosas. Mientras que la mímesis platónica aleja la obra de arte bastante del modelo ideal, que es su fundamento último, la mímesis de Aristóteles sólo tiene un punto de distanciamiento: el hacer humano, las artes de composición (1987: 88).

Según la visión aristotélica, ese alejamiento poético a través de la producción (que es de carácter metafórico) no supone la pérdida de conocimiento o esa incapacidad mecánico-técnica que 
señala Platón para conocer lo que las cosas son; sino todo lo contrario. Por la naturaleza de las cosas humanas, "contingentes" y opinables, la producción creativa es capaz de extraer lo verdadero de las cosas: "Hay algunas cosas que existen y son verdaderas pero que cabe que se comporten también de otra manera" (Órganon, Analíticos segundos, 88b, 33-35). Sobre esas cosas se puede tener intuición y opinión; y se puede acceder a ellas como asuntos prudenciales, por aproximación, acercamiento del campo de la ética (Segundos analíticos, libro primero, Sobre la ciencia y la opinión).

Para Platón, la triple degradación imitativa que desvirtúa el conocimiento $y$, por lo tanto, el acceso a la verdad es atribuible a que los poetas copian las apariencias de las cosas, porque su conocimiento es, a la vez, pobre y superficial. Como se ve, Platón pone el énfasis en los objetos y no en el origen de las decisiones ni en las acciones humanas: ése es el sustrato humano común a todos; compartido por los poetas, los imitados y la audiencia. Si, en efecto, los poetas no son como los filósofos, sus producciones tampoco lo son. Aristóteles, en cambio, considerará que la poesía es filosófica en ese sentido pues muestra lo universal (Poética, 1451b, 1-7).

Plato specifically accentuates the claim that poetry, as a form of representative arts, has been significantly removed from the idea, the philosophical interpretation of the ultimate truth specially belongs to God. (...) As a result of such empathic reasoning, Plato principally concludes his argu- ment that poetry includes no truth in itself; and therefore it significantly damages the rational elements of the human mind (Mete, 2018: 218).

Veamos algunas diferencias más en lo que se refiere al correlato de la mímesis. Como dijimos, Aristóteles se refiere a la mímesis praxeos de tres maneras en su texto de la Poética. En primer lugar, define la mímesis como acción de imitar acciones humanas y a hombres que actúan (1448 a, 1; 1448 a, 28-29). En segundo lugar, define la mímesis con más precisión como la imitación de una única acción esforzada y completa (1449b, 24). Aunque Aristóteles esté aquí definiendo la naturaleza de la tragedia, lo dicho puede extenderse a otros géneros. El mismo Aristóteles lo explica a propósito de las epopeyas homéricas (Poética, 1451a, 23-37). Aquí lo determinante es que Aristóteles especifica que lo que se representa en el conjunto de la obra y a través de personajes es una única acción. Esa única acción es la que garantiza la unidad del relato. Además dice que se trata de una acción "esforzada”. Esto significa que está en progreso, que es como si estuviera viva; que se transforma; que crece por necesidad interna, como sucede con la acción moral humana. Por ello, cabría pensar que una película o una serie pueden comprenderse en esos términos de movimiento natural que ellas mismas reproducen: resulta adecuado y pertinente valorarlas como un todo orgánico que representa una acción práctica, a través de acontecimientos, personajes con sus pensamientos y caracteres propios, peripecias, descubrimientos, que hacen 
que la acción tenga vida como un todo hacia adelante, con una finalidad final.

En tercer lugar, Aristóteles expone su idea de unidad de acción al definir la tragedia como la "imitación de una acción completa y entera, de cierta magnitud; (...) Es entero lo que tiene principio, medio y fin" (1450b, 24-26). De esto sólo diremos que, aunque aquí define la tragedia específicamente, por algunas alusiones a la epopeya y a la comedia en el texto de la Poética, también se pueden extrapolar esas características a esos y otros géneros narrativos.

Lo que importa verdaderamente es la "determinación sustancial" de la acción representada (Kieerkegaard, 2006: 162-163). Pues esa determinación extraída de las acciones prácticas reales, de lo que la gente hace, es lo que aparece puesto en toda su plenitud en la obra de ficción y además es lo que hace que se mantenga su "cohesión diegética” buscando en todo momento la unidad de acción. En resumen, la relación que se da entre la ficción y la acción práctica que quiere representar es un trabajo de "extracción" de la esencia. Una vez extraída la esencia de la materia representada -la acción real posible, el hábito real posible...- esa misma esencia es un indicador de cómo ha de contarse la historia, la acción: dirige al poeta, da coherencia a la historia y hace posible que se espeje en ella lo mejor y lo peor en esencia del obrar humano libre.

Tanto para Platón, (incluso tratándose de la mímesis degradante, el fin final está en las Ideas y en su imagen ende- ble), como para Aristóteles, (donde el fin final de la mímesis praxeos es una acción que se da a conocer, y se despliega en un nivel superior, a través del juego de transposición mimética), el referente de la mímesis es real. Para Platón es una realidad "aparencial, accidental" y para Aristóteles es una realidad "esencial, universal". La moral abre las puertas al conocimiento de lo que le es más importante de cara al progreso o deterioro vital de las personas; de su felicidad o infelicidad. A la vez que se disfruta de las representaciones, se aprende cómo somos las personas. El saber artístico no es pues inocuo.

\subsection{El segundo implicado de la míme- sis: la acción}

Veamos ahora en qué consiste que la ficción representa una acción, "el segundo implicado" de la mímesis. Esa acción se concreta en el ethos de los personajes, su pathos y sus pensamientos, diánoia; las acciones representadas se caracterizan por ser posibles y no fácticas, en el sentido histórico, aunque también es posible partir de un hecho real, para extraer el aspecto "esencial dramático", la lección de vida que esconde. Eso quiere decir que esas acciones funcionan según lo que cabe esperar, el kata to eikós o la verosimilitud: lo que, en general, todos aceptamos. En ese sentido, también pueden representarse estados de opinión, que funcionan en el relato como lugares comunes que favorecen la verosimilitud y la aceptación de la historia. Por ejemplo, pensemos aquí en los géneros cinematográficos y televisivos: los biopics (películas 
biográficas) suelen mostrar la común opinión y los lugares comunes acerca de algún personaje relevante, es decir, "su imagen mítica y pública"; sucede algo similar con los géneros temáticos acerca de instituciones y organismos públicos como el policial, el periodístico, el bélico, cuyos relatos critican, justifican o ensalzan la opinión pública. Ese tipo de mímesis equivaldría a una construcción a caballo entre lo real y la creencia: la mímesis mythos, representación de una imagen completa de una realidad aceptada, pactada y establecida en la conciencia colectiva, cuya base argumental depende de las connotaciones y significados que comparte una comunidad específica ${ }^{3}$. El mythos es la acción única y también la expresión de un conflicto vital de carácter universal que se manifiesta en la mimesis praxeos.

Aristóteles usa el término mímesis, al que cabe interpretar como imitación (de hombres que actúan) o representación (de una sola acción), con la consecuente diferencia de significado a la que apuntan ambas concreciones. Con una traducción literal de imitación, de copia, se reducen las posibilidades de estudio de la Poética (Fergusson, 1989: 12; Ehrat: 2005). Descendiendo a un nivel un poco más especializado, las glosas de Averroes sobre la Poética de
Aristóteles (Middle Commentary on Aristotle's Poetics) son una fuente de autoridad significativa para interpretar la mímesis praxeos. Entre otras razones porque el filósofo árabe interpreta la mímesis como (1) representación de la acción y (2) creación abierta a la verdad (I, 2, 1447a, 13-18; Kemal, 2003: 223). La consideración de la validez de la mímesis praxeos, como proposición abierta al juicio de verdad o falsedad, nos indica el carácter racional poético, como se verá, a propósito del silogismo poético: la gran aportación de los comentaristas árabes. Esa base argumental descrita para las obras poéticas puede parecer irrelevante para la vida práctica de escritores y guionistas. Pero la realidad dice que una historia mal contada es una historia sin sentido. $\mathrm{Y}$ eso es lo que precisamente protegen los "silogismos poéticos" bien hechos. Si las ficciones se entienden es porque se sostienen por la misma racionalidad que las personas comprendemos en la vida real. De lo contrario, las ficciones se vuelven ininteligibles, cerradas sobre sí mismas y falseadoras, también (Gutiérrez, 2008; Torrado, 2017).

Recordemos que una solución al problema de cómo se representa la acción se encuentra en otras obras de Aristóteles. Respecto a la segunda parte

3 El concepto de mímesis mythos se debe distinguir del binomio mímesis- mythos a través del cual Ricoeur explica los dos aspectos esenciales del arte poética: la representación y la fábula u organización de los hechos (1987: 89). En ese caso, el referente y la base de la racionalidad poéticas se encuentran en la relación entre el mythos y la mímesis (Ricoeur, 1980: 329). La definición de la mímesis como la dimensión denotativa del mythos explica una relación. Pero acaso es el mythos el conjunto de acciones posibles o la acción única a la que se refiere Aristóteles, que no habla de mímesis aislada o de "mímesis mythos". En este punto, Ricoeur se aventura, razonablemente, a ampliar el área de lo metafórico por extensión a toda la realidad humana y a "sus retratos de la vida interior" a los que designa como fuentes simbólicas del discurso (1980: 331). 
de la expresión mímesis praxeos, esto es, la praxeos, tanto Toulmin (2006: 10) como Fergusson (1989: Prol.) recomiendan un estudio comparativo con la Ética, la Política, la Retórica y Acerca del alma. Por ejemplo, Fergusson (1989: 12) entiende por esa expresión la representación del "movimiento del espíritu", como una síntesis entre la acción y la pasión, y los llamados "afectos" desde el punto vista psicológico. En esta misma línea, se incluirían otros objetos referenciales posibles, según sea su peso en la trama: los pensamientos o las ideas reflexionadas. Ejemplos de este tipo de mímesis poética son el cine propagandístico, el ideológico y el filosófico. Sin excluir que exista acción en ellos, claramente predomina el peso de una reflexión, de una idea que condiciona la evolución de la fábula. Por lo tanto, podríamos proponer que (1) si la relación de la representación se establece más con la acción, la mímesis podrá interpretarse como mímesis praxeos; (2) si la relación se inclina más hacia la representación de la pasión, podría denominarse mejor como mímesis pathos; y (3) si la relación mimética se establece más explícitamente con un pensamiento o idea, se trataría de concretar el mythos sobre todo como una mímesis diánoia (recuérdese que sobre el estudio del pensamiento, Aristóteles nos remite a la Retórica, "pues es más propio de aquella disciplina". En ella describe las funciones del uso del pensamiento: "demostrar, refutar, despertar pasiones $[\ldots .$.$] ",$ $\left.1456^{\circ}, 19,34-1456 \mathrm{~b}, 1\right)$.

Esas tres distinciones básicas del objeto referencial de la relación pueden cambiar el curso de la acción y generar un tipo de narración, de trama, de fábula distinta; el énfasis argumental también difiere por tanto. Se diría que los géneros audiovisuales y los formatos de historias dependen en buena medida del tipo de mímesis "moral" o de relación mimética de que se trate.

Como sugirió Averroes, al interpretar la mímesis aristotélica como representación, el asunto poético es en definitiva un asunto moral. Por ello aquí conviene recordar la mímesis platónica, que tuvo mucha influencia en la interpretación que hizo Averroes de Aristóteles, en la medida en que, ante la imposibilidad que atribuye Platón a la mímesis de alcanzar toda verdad, recomienda a los poetas contar historias ejemplares y con una finalidad didáctica. Este mandato puede entenderse como una recomendación moral, pero de aparición exógena a la representación, esto es, impuesta artificialmente al "movimiento" representado. Por lo tanto, en sentido estricto, podemos afirmar que Platón tiene una idea conceptual y no moral de la mímesis en sí, aunque en apariencia se pueda concluir lo contrario por el temor que se suscita precisamente desde el punto de vista ético. Platón considera que la mímesis presenta "una separación ontológica de la realidad verdadera y que posee un potencial para subvertir la conducta del individuo como del estado" (Golden, 1992: 42). Para Platón, la mímesis es eikasia, copia superficial externa del objeto (Juan-Navarro, 2007: 105). Pero si bien alerta de la corrupción y la degradación moral que puede generar el producto 
de la mímesis sobre las personas (alterando su comportamiento), también cree que puede haber una poesía "filosófica" (Golden, 1992: 41-42). Eso sucede si el poeta participa de la noesis (un acceso a los principios) y se ve así inspirado en su labor poética por las musas (República, III, VI, X). En ese caso, y sólo así, la relación entre la poesía (pongamos ficción) y el mundo ideal (transferido a través de la inspiración) será posible. El poeta aprenderá qué son las cosas por connaturalidad, esto es, empatizando con la realidad e integrando en su trabajo poético dos naturalezas: la natural de la acción y la artificial del objeto poético. De su acto contemplativo puede surgir una obra para la contemplación en la que el espectador va a ser capaz de ver la naturaleza de la acción en el sentido del relato.

En suma, al reflexionar sobre la concepción "lógica" de la mímesis, según Platón, como copia triplemente degradada de las Formas, la desvincula de la praxis; rompe la relación, la desvirtúa, y la vuelve estática y no dinámica, como es propio de la relación con algo tan vivo como la vida humana. La "ideologización" de la mímesis supone una ruptura con el fundamento natural necesario de la acción; ahí la relación de semejanza es sólo conceptual-abstracta, simulada y aparencial. Pero en la visión de la mímesis aristotélica la relación con la acción práctica constituye el origen de la trama y su finalidad, de modo que la ficción empieza fuera $y$ acaba fuera de ella misma. Y con Ricoeur afirmaríamos que, además, la trama representa el movimiento de la acción, actúa "como si" fuera una acción (1987: 89).

Podríamos suponer que existe una distinción entre el qué se representa y la fábula, como trama que representar ese qué. Ambas partes en definitiva se relacionan. De hecho, en este punto es pertinente traer a colación la distinción que hace Aristóteles entre el relato histórico y el relato de ficción. En el primero, la organización de los hechos depende del hecho sucedido, y en el segundo, la trama queda supeditada a la acción posible: “ (...) no corresponde al poeta decir lo que ha sucedido, sino lo que podría suceder, esto es, lo posible según la verosimilitud o la necesidad. En efecto, el historiador y el poeta no se diferencian por decir las cosas en verso o en prosa (...); la diferencia está en que uno dice lo que ha sucedido y el otro lo que podría suceder" (Poética, 1451a, 9, 38-40 - 1451b, 1-5). De hecho, al dar algunas recomendaciones sobre cómo escribir epopeyas, el mismo Aristóteles establece que "no deben ser semejantes a los relatos históricos, en los que necesariamente se describe no una sola acción, sino un sólo tiempo, es decir, todas las cosas que durante él acontecieron a uno o a varios, cada una de las cuales tiene con las demás relación puramente casual" (1459a, 22-24). Así pues la relación de semejanza del relato histórico (su organización interna y su necesidad) con la acción real, a la cual busca asemejarse, es distinta de la relación entre el relato de ficción (su organización interna y su necesidad) y la acción real posible (y universal), a la cual busca adecuarse. 


\section{Los principios de la relación}

Llegados a este punto, es necesario recapitular acerca de los rasgos de la representación de la acción (mímesis praxeos aristotélica) para comprender las consecuencias derivadas para la ficción que tienen (1) la afirmación del referente, (2) la relación de semejanza y (3) una racionalidad poética abierta al juicio de verdad.

En este sentido, en el origen de la adecuación por semejanza actúan dos principios esenciales: el principio de analogía y el principio de identidad. Ambos han de estar presentes de manera relativa (y quizá poco explícita) en el proceso creativo del mythos. Por principio de analogía, Aristóteles entiende una trasmutación de significados o sustitución (Poética, $1457 \mathrm{~b}, 17-20)$. Ese principio es una de las causas de la metáfora (que también se origina por traslación del género a la especie de la especie al género o de un género a otro género, siempre por vincularse o mantener un nexo o lazo relativo en el significado). Esa relación de semejanza entre las cosas le corresponde al poeta/ escritor/ guionista advertirla y transformarla en algo nuevo.

En lo que respecta al propósito de esta investigación, la metáfora sería el culmen de ambos principios, su resultado más convincente, ese "algo nuevo". Pues ella es el fruto del proceso de concentración figurada o "concentración sin eliminación”, según Labrada (1998), a través del cual la acción real posible puede quedar representada en la ficción sin pérdida de su estatuto ontológico, sin pérdida de verdad. Podemos definir ese proceso como una operación de concentración o contracción, por usar la expresión de Nicolás de Cusa ${ }^{4}$. Pero, a la par, la visión del poeta es siempre una visión limitada. Por tanto, en la representación de la acción se da una paradoja: convergen la esencia de la acción y la visión subjetiva del autor. De esa combinación casi imposible que se da en el acto poético nacen unas relaciones argumentativas que persiguen explicar lo esencial implicado en la acción única de una manera genuina y novedosa. Por ello, la racionalidad de la ficción está asistida por el referente real posible y es creativa porque el modo en que aparece es el modo del poeta. Según se incline la balanza hacia un lado u otro, el relieve será para el autor o para la objetividad de la acción.

A este respecto, para responder a la pregunta de cómo el lenguaje pasa a ser medio de creación en Aristóteles, Genette sugiere lo siguiente:

La respuesta de Aristóteles es clara: sólo puede haber creación por el lenguaje, si éste se convierte en vehículo de mímesis, es decir, de representación o mejor dicho, de simulación de acciones y acontecimientos imaginarios, si sirve para inventar historias o, al menos, para transmitir historias ya inventadas. El lenguaje es creador cuando se pone al servicio de la ficción

4 Dejamos el estudio sobre la "visión contracta" o imagen humana de las cosas, en Nicolás de Cusa para próximas investigaciones. 
(...). Para Aristóteles, la creatividad del poeta no se manifiesta en el nivel de la forma verbal, sino en el de la ficción, es decir de la invención y la disposición de una historia (1993: 16).

En ese mismo sentido, Ricoeur habla de la imaginación creadora ${ }^{5}$ que en su función de metaforizar es capaz de "percibir lo semejante": "La imaginación creadora que actúa en el proceso metafórico es así capaz de producir nuevas especies lógicas por asimilación predicativa, a pesar de la resistencia de las categorizaciones usuales del lenguaje" (1987: I, 34). Esto es, a pesar de que el lenguaje tiende a ser descriptivo, literal y convencional, cuando actúa metafóricamente, se despega de los significados de siempre para generar nuevas combinaciones. Por tanto, Ricoeur centra su atención en el aspecto de cómo una novedad creativa remite a su vez a lo conocido; de cómo, en definitiva, aunque se trate de una ficción de fantasía, en aparente discordancia con el mundo real, el referente humano sigue estando presente, si la representación es poética y si la relación veraz.

Además de crear nuevas combinaciones creativas, metáforas ejemplificadoras, la trama es coherente, densa, está cohesionada y es universal si en el trabajo de relacionar (y "tomar juntos asuntos dispersos", Ricoeur, 1987: I, 34) se ha visto la semejanza en la discordancia de entre distintos asuntos reales. Por ello, Ricoeur afirma que "pensar un vínculo de causalidad, incluso entre acontecimientos singulares, es ya universalizar" (1987: 99). En definitiva, Ricoeur atribuye a la ordenación la universalidad del contenido: "La conexión interna es el inicio de la universalización”. Y así la ficción se hace inteligible: se logra el reconocimiento y reencuentro deductivo al que se refiere Aristóteles al hablar del placer de aprender a través de las representaciones ("deducir qué es cada cosa; por ejemplo, que éste es aquél”, 48b, 17). En esa misma línea, Ricoeur afirma que "inventar es reencontrar" (100). Abundando en esta idea podemos afirmar que reencontrar es también poner en relación. Pero "el creador de palabras no produce cosas, sino sólo cuasi-cosas; inventa el como-si” (106).

Antes de explicar qué es el "como si", Ricoeur resume la actividad poética en tres fases (1987: 134-135): (1) la comprensión del obrar humano y su realidad simbólica; (2) la configuración narrativa o disposición de los hechos que es mediadora e integradora de contrarios; y (3) el juicio comprensivo de la recepción, que es posible gracias a que "las obras poéticas se refieren al mundo según un régimen referencial propio, el de la referencia metafórica" que consigue crear una "nueva pertinencia" en el "plano del sentido, sobre las ruinas del sentido literal abolido por su propia impertinencia”. Este es el trabajo ontológico que genera la metáfora con el "ser-como" (1987: 156-157). Éste es en

5 Para un mayor desarrollo sobre las funciones de la imaginación y, en concreto, sobre la idea "imaginación creadora" en P. Ricoeur, cfr. Begué, M-F. (2002). Paul Ricoeur: La poética del sí-mismo, Buenos Aires: Biblos, pp. 25-100. 
definitiva el trabajo al que se dedican los creadores de ficciones: crear nuevas pertinencias gracias a la relación.

\section{1. El silogismo poético: proposicio- nes relativas por semejanza}

Para entender cómo se argumenta a través de una ficción hay que explicar el silogismo poético. Éste es el sustrato proposicional, la red argumental lógica o el modo de componer una relación de semejanza desde el punto de vista poético. Gracias a los silogismos poéticos, las acciones prácticas encuentran un acomodo "racional": parecen "someterse" a una recreación llena de sentido. En ese proceso silogístico, la acción dramática (el mythos) "adquiere" el significado práctico que tiene en la vida real la acción de la que habla. Diremos que la ficción "sufre" por contagio el significado vital de la acción práctica contemplada en su completud. Por ello, es posible que, una vez contemplada por los espectadores, esa acción dramática remueva sus conciencias, predisponiéndolos a reflexionar sobre su vida, a cambiar sus sentimientos y moverse a la acción. De ahí la presunta ejemplaridad que se atribuye a las representaciones o comunicabilidad social de lo real posible. Como receptores, lo que aceptamos a través de las ficciones son "argumentos de vida" para hacer una cosa o su contraria. Así el principal escollo que aparece es el de la de-mostración (y no sólo el carácter creativo-metafórico que tiene) de la relación entre ambas acciones (la práctica y la dramática).

En su intento por dar validez al significado poético de las ficciones, otro de los grandes comentaristas árabes de Aristóteles, Alfarabi, estudia su base lógica (Kemal, 2003: 31). Tengamos en cuenta que, según Kemal, los aristotélicos árabes consideraban que la Poética era un libro que formaba parte del Órganon (30). El sentido de esta afirmación es pertinente. Por ejemplo, Alfarabi señala que los símiles y las comparaciones no son otra cosa que silogismos poéticos (2003: 57). Soñar con las ficciones y reproducirlas en nuestra conducta se debe en parte a su poder "convincente" no irracional necesariamente. Así mismo, según Kemal, Avicena explica la estructura silogística en la poesía como el efecto de la imaginación, "the ability to reproduce sensory experiences as mental images, even in the absence of the objects which caused these experiences" (Kemal, 2003: 83). Y va más allá al explicar por qué se produce la identificación con esas imágenes creadas que evocan la realidad: "Representation, [Avicena] he explains, "preserves what the sensus communis has received from the individual five senses, even in the absence of sensible objects" (Avicena en Kemal, 2003: 83). Avanzando en esta línea y tomando como objeto la acción ausente de la relación en la mímesis praxeos, nos preguntamos cómo afecta la acción real a las personas, a sus vivencias afectivas, incluida la memoria y las actitudes, que ella deja como huella. Pues más que un objeto sensible, la acción es un asunto vital del que se tiene constancia por la experiencia. También Averroes al definir la poética como "the art of making representative statements" (en Butterworth, 1986: I, 3, 1447b, 18-27) 
remarca el sustrato lógico de la mímesis poética. Al usar en sentido general el concepto de imitación y el de representación, como una especie de imitación, Averroes señala también que la imitación representativa puede ser metonímica o metafórica. Es decir, no sólo creativa, desde el punto de vista del uso del lenguaje y de la nueva atribución, sino subrayando que el discurso mimético se da por sustitución. Y la sustitución, como indica el filósofo árabe, es una figura que corresponde al estudio de la retórica (Averroes en Butterworth, 1986: 1, 2, 1447a, 13-18). Si algo sustituye a otra cosa es porque comparten una relación que, de alguna manera, los presenta como equivalentes.

La ficción audiovisual también ofrece sensorialmente imágenes materiales, pero sin espacio para la imaginación subjetiva del receptor; es decir, limitando el campo de la racionalidad, su comprensión, evocación y sentido, a lo visto y oído en ella, y articulado para convencer y demostrar su veracidad en el relato (y no sólo en la imagen que evoca el relato). En ese sentido, la organización de los hechos en el drama audiovisual es determinante para convencer del silogismo poético (el conjunto de proposiciones entrelazadas en búsqueda de un sentido más allá del texto).

\subsection{Aspectos retóricos del silogismo poético}

Como decíamos, algunos autores como Ricoeur (1980), Fergusson (1989) o Golden (1992) han contextualizado la Poética en relación con otras obras de Aristóteles. Por ejemplo, en lo que res- pecta a la Retórica, en ella también se expone qué significa usar la metáfora para ejemplificar, convencer de un argumento y mostrar una imagen que persuada de algo. El decir metafórico no es un decir directo sino estratégico, en la medida en que su función principal es cautivar.

De nuevo, Ricoeur aporta un análisis certero sobre la dependencia entre los aspectos dinámicos y problemáticos del discurso de verdad, incluyendo en él el de la verdad metafórica. Para ello retoma la relación entre la Retórica y la Poética que establece Aristóteles en la metáfora (1980: 20-23; Poética, 1457b, 7-9). La analogía metafórica designa, según Ricoeur, un "debilitamiento progresivo de la precisión de la función" del ser (1980: 355). Ese debilitamiento al que se refiere Ricoeur se debe a que el lenguaje deja de designar descriptivamente la realidad para desviarse en busca del sentido de la realidad. Pero Aristóteles, sigue diciendo el mismo Ricoeur, sostiene que la analogía no es exactamente un debilitamiento de la derivación del ser, sino la constatación de la existencia de los accidentes como movimientos del ser: “(...), donde hay algo que se hace, es posible la predicación: ésta se establece sobre la disociación física introducida por el movimiento" (360). Trasladado a la poética audiovisual, la ficción reinterpreta en clave de sentido todas esas alteraciones accidentales pero que explican su relevancia: cada uno de esos accidentes casi imperceptibles en la vida real de los hombres se convierte en materia de la fábula, como organización de los hechos (pragmaton systasis). 
La analogía es un principio que condiciona el establecimiento de relaciones entre el ser y sus estados y además trata de transponer atributos similares entre dos asuntos diversos. Es decir, el poeta, el escritor y el guionista generan la comparación entre el objeto poético y las características de objetos reales (acciones, principalmente) en las que encuentra semejanzas. Sin la semejanza no será posible la relación de identidad entre ambas. Por tanto, la relación de analogía en Aristóteles no indica la naturaleza del objeto sino que tan sólo expresa una relación que permite pensar y conocer las cosas por aproximación. Cuando Aristóteles distingue los fines del discurso científico y el poético no se refiere a una ruptura en la unidad del ser, sino a modos de abordar aspectos, distingue por definición la naturaleza del ser en sí de la del ser en movimiento, en concreto, de la acción del ser humano que decide.

En coincidencia con Aristóteles, Ricoeur reconoce que la analogía se da por participación y que esa participación implica un "cruce de modalidades de transferencia”, según la prioridad y según las significaciones derivadas (1980: 378-379). Es decir, que se intercambian significados a causa de la relación escondida: ésa es la fuente de la argumentación silogística. Aristóteles pone en relación la metáfora con la analogía en la Retórica: "Es preciso decir los epítetos y las metáforas bien apropiadas, lo cual se logrará por analogía, (...)"(Retórica, III 2, 7-11) y "es preciso sacar la metáfora, como se ha dicho, de cosas propias, pero no obvias; según también en filosofía contemplar lo semejante aún en lo que se diferencia mucho es propio del sagaz (...)" (Retórica, III 11, 1412a, 10-15). Ricoeur en cambio distingue la función de la metáfora en la retórica y en la poética: al querer recuperar el lugar de la argumentación, entiende que el discurso poético es una representación que no busca probar nada -más bien sólo redescribir inventivamente algo- y en ese sentido, se parece más al discurso epidíctico, por el que es posible establecer un juicio de verdad (García-Noblejas, 1996). Para comprender esto, hay que pensar en él como un discurso reemplazativo. Sin embargo, en el discurso retórico, el ejercicio de la argumentación es condición necesaria para persuadir y convencer a la audiencia. Si como afirma Ricoeur "la poesía no es elocuencia" (1980: 21), la trama (la organización de los hechos: el pragmaton systasis) del mythos tampoco es argumental, en algún sentido. Ahora bien, el sentido común dice que los poetas en las ficciones argumentan formas de ver la vida, de convencer sobre lo dicho, seleccionando y orquestando lo seleccionado. Eso constituye la función común de la poética con otros saberes prudenciales: “(...) saber decir lo implicado en la acción y lo que hace al caso, lo cual, en los discursos, es obra de la política y de la retórica" (Poética, 1450b, 4-8). Esto es: el proceso representativo no persigue sólo concluir el mythos (como mimesis praxeos), sino que se convierte en vehículo de conocimiento, proceso de una búsqueda, sobre la parte incierta de las acciones humanas, 
con las que mantiene una relación en tensión constante.

Tanto con la Retórica como con la Poética hay que ser convincente por distinta razón. La elección de los elementos semejantes que configuran la unidad de acción del drama "porque vienen al caso" ya constituye un ejercicio de argumentación: el poeta ha de encontrar razones implicadas -y crear argumentos silogísticos- para convencer de la relación de semejanza, de la verosimilitud y de la coherencia de la historia con el referente ausente (la acción real posible).

Quizá por ello Ricoeur encuentre finalmente una conexión con la argumentación, al definirla como "estrategia del discurso por la que el lenguaje se despoja de su función de descripción directa para llegar al nivel mítico en el que se libera su función de descubrimiento" (1980: 332). Así plantea la existencia de una "intención realista", de una estrategia metafórica -más creativa si se quiere que en la retórica- que parece escapar del como si para parecer que es. Con la elocuencia se busca convencer, pero con la poética se busca mostrar, como en el discurso especulativo (Ricoeur, 1980: 332-346; GarcíaNoblejas, 1982: 467-468; 1996: 221).

Como ha quedado dicho, la cuestión es si en realidad la poética trata de convencer también de que se muestra algo que es. En la medida en que existe intencionalidad en la selección y el orden de la causalidad de los hechos, estamos ante una demostración subrepticia de algo, cuya estrategia permite, eso sí, aceptarla como muestra de algo. Dar credibilidad a lo posible-relativo-semejante de las acciones humanas, siguiendo los cauces de la verosimilitud (Poética, 1451a, 36-39) es pues un asunto de retórica poética.

En tanto que la representación está por la existencia de la acción real posible y participa de ella, en el relato de ficción se ha de demostrar que participa y que existe por ella. El acto creador metafórico no excluye la necesidad de probar argumentalmente, dado que necesita convencer de la "consistencia" o calidad real (algo muy serio, si se mira bien) de esa representación. De hecho, según Munteanu (2004: 61), el pathos aristotélico está conectado con la racionalidad e incluso "forma parte de la prueba lógica, que hace aceptable la argumentación del orador". Cabría suponer que la retórica constituye más un saber sobre cómo manejar las emociones en los argumentos, en la medida en que, sin ser racionales, han de someterse y guiarse a través de la argumentación en un "proceso de razonabilidad" (Munteanu, 2004: 61-62). Ese proceso de razonabilidad está presente en la ficción de manera particular.

La semejanza que se establece entre la ficción y la realidad no es pues una semejanza empírica (Eco, 1972). Lo poéticamente verosímil de la organización de los hechos requiere de una buena argumentación. Y es esa argumentación la que implica una relación de identificación, pero sólo en el sentido figurado o metafórico, que separa parcialmente a la representación (p.ej. El árbol de la vida, West Wing, Breaking Bad, Stranger Things, The Searchers...) de lo representado (qué 
es la vida; cómo es el gabinete de comunicación de la Casa Blanca; cómo es la ambición de un hombre con talento y poca autoestima; cómo sería convivir con un mundo paralelo lleno de horror que entrara en el mundo natural; cómo salir de la sombra del odio...): se trata de asuntos diversos que pasan a ser idénticos por asociación de semejanzas. Para Ricoeur, se trata de una "traslación de la significación de los nombres” (1980: 25). Pero, en definitiva, lo que se traslada a la acción es el movimiento psíquico representado como una forma de energeia, la fuerza del obrar algo. Fergusson define esa acción como el obrar habitual, que no corresponde a la "acción pura" sino a una combinatoria entre la acción y la pasión, la praxis y el pathos (1989: 12).

Por último, la extrapolación del conocimiento a nuestras vidas es función del silogismo poético (Munteanu, 2004: 58). También lo entiende así Avicena, que considera que el lenguaje figurativo se hace cargo de "the relation 'among the parts' y que esa relación metafórica es la conclusión de un silogismo válido en términos de verdad (Avicena en Kemal, 2003: 100). Si la justicia poética está anclada en la lógica de la acción moral, se logra "estimular la evaluación moral" de los espectadores en sus vidas (Appel, 2008: 64). Así la función retórica en la ficción puede entenderse como algo más que la mera búsqueda de hacer creíble lo representado: articulando argumentos representa por semejanza los aspectos inconscientes del obrar. Esta articulación emerge de la propia lógica representativa de manera natural (Styan, 1963: 163), de ahí que concluya- mos que argumentar es un acto en defensa de la justicia en el seno y fuera de la representación.

\section{Conclusiones}

La relación, como categoría que establece semejanzas entre las cosas, es el vínculo que articula razones y argumentos poéticos en búsqueda de la propiedad exclusiva o necesaria (no meramente cultural ni particular) del objeto que se quiere representar, esto es, de la acción práctica humana.

El estudio de la relación puede explicar el tipo y el grado de participación de la acción dramática en su referente real. La fuente de la representación, según la Poética de Aristóteles y la tradición de comentaristas árabes, es la acción moral (Averroes in Butterworth, 1986: ii, 8, 1448a, 1-11). Por ello, la acción moral representada es el origen del discurso de ficción (mimesis praxeos), que, articulado poéticamente como metáfora, busca una nueva manera de manifestarse (mythos); la acción es también el origen de la organización de los hechos (pragmaton systasis), que obedece al esfuerzo por expresar el curso de la acción real a la luz del sentido que tiene: expandiendo hasta sus últimas consecuencias todo su beneficio moral o su inmoralidad. En ese despliegue, en el que se despiertan las emociones pedagógicas del temor y la compasión, también corresponde mostrar las emociones anexas a cada una de las tonalidades menores de la praxis (sintonizadas, armonizadas, sublimadas, violentadas, contenidas, inconscientes, etc.); y así, habiendo creado un modo de suscitar 
emociones mostrando el valor que para las personas tiene el ejercicio de la libertad, esa praxis simbólica y coexistente ofrece un aporte de conocimiento esencial, por un lado, y posicionado, por otro, pues alguien (el poeta) tiene que establecer la relación. Por ello, la necesidad que traslada la relación a la ficción poética es selectiva, en el sentido apuntado por Aristóteles, cuando anima a los poetas a descartar episodios irrelevantes para alcanzar el sentido (el fin único) de la única acción (1451a, 16$37)$; y racional, pues la necesidad y ve- rosimilitud constituyen un eje que persigue no entrar en contradicción.

Desde el punto de vista de la lógica poética, aún queda mucho terreno por explorar. Pero un primer paso lo constituye el hecho de que tengamos evidencias de que existe esa lógica que no es autónoma y que mantiene un nexo de identidad figurada con la realidad de la acción: el cómo de la comparación. La acción dramática sólo será acción si existe por la acción práctica. Por lo tanto, necesariamente el referente está presente en la representación por relación.

\section{Bibliografía}

Appel, M. (2008), "Fictional Narratives Cultivate Just-World Beliefs", en Journal of Communication, 58, 62-83.

Aristóteles (1972). Ética a Nicómaco, Barcelona: Colección Austral.

Aristóteles (1982). Órganon, Madrid: Editorial Gredos.

Aristóteles (1990). Retórica, Madrid: Centro de estudios constitucionales.

Aristóteles (1995). Física, Madrid: Editorial Gredos.

Aristóteles (1974). Poética, Madrid: Editorial Gredos.

Averroes (1989). Middle Commentary on Aristotle's Poetics, edición de Charles E. Butterworth, Princeton: Princeton University Press.

Barthes, R. (1977). Introducción al análisis estructural de los relatos. Buenos Aires: Centro Editor de América Latina.

Begué, M-F. (2002). Paul Ricoeur: la poética del sí-mismo, Buenos Aires: Biblos.

Brenes, C. S. (2011). "The Practical Value of Theory: Teaching Aristotle's Poetics to Screenwriters", en Comunicación y Sociedad, 24 (1), 101.

Brenes, C. S. (2016). "Explorando el tema. La noción poética de "sentido" al servicio de la escritura de guion”, en Revista de Comunicación, 15, 166-182.

Carr, D. (2006). "Moral education at the movies: on the cinematic treatment of morally significant story and narrative”, en Journal of Moral Education, Vol. 35, No. 3, September: 319-333.

Casado, C. \& Colomo, R. (2006). Un breve recorrido por la concepción de las emociones en la Filosofía Occidental, en A parte rei. Revista de Filosofía, 47, septiembre.

Eco, U. (1972). La estructura ausente, Introducción a la semiótica, Barcelona: Editorial Lumen.

Eco, U. (1976), Introducción al estructuralismo, Madrid: Alianza.

Ehrat, J. (2005). Cinema \& Semiotic. Peirce and Film Aesthtetics, Narration, and Representation, Toronto: UTP. 
Fergusson, F. (1989). Aristotle's Poetics, New York: Dramabook, Hill \& Wang.

Ferraris, M. (1999). La imaginación, Madrid: Visor.

Field, S. (1995). El libro del guión. Fundamentos de la escritura de guiones, Madrid: Plot ediciones.

Frago, M. (2005). "Reflexiones sobre la adaptación cinematográfica desde una perspectiva iconológica”. Communication and Society, Vol. XVIII, 2: 49-82.

Frow, J. (1995). Cultural Studies and Cultural Value, Oxford: Oxford University Press.

García-Noblejas, J. J. (1982). Poética del texto audiovisual, Pamplona: Eunsa.

García-Noblejas, J. J. (1988). “Fundamentos para una iconología audiovisual”, en Comunicación y Sociedad, 1 (1): 21-71.

García-Noblejas, J. J. (1996). Comunicación y mundos posibles, Pamplona: Eunsa.

Golden, L. (1992). Aristotle on Tragic and Comic Mimesis, Atlanta: Scholar Press.

Green, M. C., Brock, T. C. \& Kaufman, G. F. (2004). "Understanding Media Enjoyment: The Role of Transportation Into Narrative Worlds", en Communication Theory, 14, 4, November: 311-327.

Greimas, A. J. (1987). Semántica estructural. Investigación metodológica, Madrid: Gredos.

Gutiérrez, R. (2008). "La falacia dramática y la representación de la familia en la ficción televisiva. Comparativa poética entre Médico de familia, Los Serrano y Cuéntame cómo pasó”, en Medina, M. (co.), Series de televisión. El caso de Médico de familia, Cuéntame cómo pasó y Los Serrano, Madrid: Eiunsa.

Halliwell, S. (1998). Aristotle's Poetics. Chicago: Chicago University Press.

Halliwell, S. (2002). The Aesthetics of Mimesis. Ancient Texts and Modern Problems, Princeton: Princeton University Press.

Heidegger, M. (2000). Hölderlin y la esencia de la poesía, Barcelona: Anthropos.

Juan-Navarro, S. (2007). "The power of mimesis and the mimesis of power: Plato's concept of imitation and his judgment on the value of poetry and the arts", en Studium. Revista de Humanidades, 13, 97-108.

Kayser, W. (1985). Interpretación y análisis de la obra literaria, Madrid: Editorial Gredos.

Kemal, S. (2003). The Philosophical Poetics of Alfarabi, Avicenna and Averröes. The Aristotelian Reception, London: Routledge.

Kovala, U. (2014). “Theories of Context, Theorizing Context”, en Journal of Literary Theory, 8 (1): 158-177.

Macdonald, I. W. (2003). "Disentangling the Screen Idea”, en Journal of Media Practice, 5 (2), 89-100.

Macdonald, I. W. (2013). Screenwriting Poetics and the Screen Idea, London: Palgrave Macmillan. Mete, B. (2018). "Mimetic Tradition and the Critical Theory, en Selçuk Üniversitesi Sosyal Bilimler Enstitüsü Dergisi (Selçuk University Journal of Social Sciences Institute); (39), 216-224.

Munteanu, D. (2004). Ancient spectator of tragedy: Facets of Emotion, Pleasure and Learning, tesis doctoral inédita, University of Cincinnati.

Labrada, M. A. (1994). Sobre la razón poética, Pamplona: Eunsa.

Llano, A. (2014). "La ficción como modo de conocimiento", en Bergamino, F. Alicia detrás del 
espejo. Literatura y conocimiento de la realidad, San José: Promesa.

Ricoeur, P. (1980). La metáfora viva, Madrid: Ediciones Europa.

Ricoeur, P. (1987). Tiempo y narración, I y II, Madrid: Ediciones Cristiandad.

Ricoeur, P. (2000). "Narratividad, fenomenología y hermenéutica”, en Anàlisi, 25, 189-207.

Scaramuzzo, G. (2016). "Aristotle's homo mimeticus as an Educational Pradigm for Human

Coexistence", en Journal of Philosophy of Education, vol. 50, No. 2, 246-260.

Slack, J. D. (2006). “The Theory and Method of Articulation in Cultural Studies”, en Chen, J- H \& Morley, D. (eds.). Stuart Hall. Critial Dialogues in Cultural Studies, London: Routledge. Slomkowski, P. (1997). Aristotle’s Topics, Leiden: Brill.

Torrado, D. (2017). La falacia dramática en la ficción televisiva nacional y su relación con los índices de audiencia. Análisis del medio televisivo en términos de mercadotecnia. El caso de los Hombres de Paco. Tesis doctoral inédita. Universidad de Sevilla. Presentada en Madrid.

Toulmin, S. (2007). Los usos de la argumentación, Barcelona: Península.

Verdenius, W. J. (1949). Mimesis. Plato's Doctrine of Artistic Imitation and its Meaning to us, Leiden: E. J. Brill. 